\title{
A Physical Map of the Syringomycin and Syringopeptin Gene Clusters Localized to an Approximately 145-kb DNA Region of Pseudomonas syringae pv. syringae Strain B301D
}

\author{
Brenda K. Scholz-Schroeder, ${ }^{1}$ Jonathan D. Soule, ${ }^{1}$ Shi-En Lu, ${ }^{1}$ Ingeborg Grgurina, ${ }^{2}$ \\ and Dennis C. Gross ${ }^{3}$ \\ ${ }^{1}$ Department of Plant Pathology, Washington State University, Pullman 99164-6430 U.S.A.; ${ }^{2}$ Dipartmento di \\ Scienze Biochimiche 'A. Rossi Fanelli,' Università 'La Sapienza' di Rome, Italy; ${ }^{3}$ Department of Plant \\ Pathology and Microbiology, Texas A\&M University, College Station 77843-2132 U.S.A. \\ Submitted 2 April 2001; Accepted 5 September 2001.
}

Genetic and phenotypic mapping of an approximately 145-kb DraI fragment of Pseudomonas syringae pv. syringae strain B301D determined that the syringomycin (syr) and syringopeptin (syp) gene clusters are localized to this fragment. The syr and syp gene clusters encompass approximately $55 \mathrm{~kb}$ and approximately $80 \mathrm{~kb}$, respectively. Both phytotoxins are synthesized by a thiotemplate mechanism of biosynthesis, requiring large multienzymatic proteins called peptide synthetases. Genes encoding peptide synthetases were identified within the $s y r$ and syp gene clusters, accounting for $90 \%$ of the DraI fragment. In addition, genes encoding regulatory and secretion proteins were localized to the DraI fragment. In particular, the salA gene, encoding a regulatory element responsible for syringomycin production and lesion formation in $P$. syringae pv. syringae strain B728a, was localized to the syr gene cluster. A putative ATP-binding cassette $(\mathrm{ABC})$ transporter homolog was determined to be physically located in the syp gene cluster, but phenotypically affects production of both phytotoxins. Preliminary size estimates of the syr and syp gene clusters indicate that they represent two of the largest nonribosomal peptide synthetase gene clusters. Together, the syr and syp gene clusters encompass approximately $135 \mathrm{~kb}$ of DNA and may represent a genomic island in $P$. syringae pv. syringae that contributes to virulence in plant hosts.

Additional keywords: lipopeptide toxin, necrosis-inducing phytotoxin, virulence determinant.

Pseudomonas syringae pv. syringae is one of the most abundant bacterial plant pathogens in nature (Bradbury 1986). The bacterium characteristically produces two classes of necrosis-inducing lipopeptide phytotoxins, syringomycins and syringopeptins (Bender et al. 1999; Gross 1991; Iacobellis et al. 1992). Both the syringomycins and syringopeptins are am-

Corresponding author: D. C. Gross; Telephone: +1-979-845-8288; Fax: +1-979-845-6483; E-mail: dgross@ppserver.tamu.edu

* The $e$-Xtra logo stands for "electronic extra" and indicates the HTML abstract available on-line contains supplemental material not included in the print edition. Figure 2 is in color on-line. phipathic molecules composed of a hydrophobic 3-hydroxy carboxylic acid tail of varying lengths and a charged cyclic peptide head (Ballio et al. 1995; Fukuchi et al. 1992; Segre et al. 1989; Vaillo et al. 1992). It is the amphipathic nature of these phytotoxins that enables them to insert into membranes and form pores that ultimately lead to plant cell death (Hutchison and Gross 1997).

Recent genetic and biochemical analyses demonstrated that both the syringomycins and syringopeptins are synthesized by a nonribosomal mechanism of peptide biosynthesis (Grgurina and Benincasa 1994; Guenzi et al. 1998; Scholz-Schroeder et al. 2001; Zhang et al. 1995). This mechanism utilizes large multifunctional peptide synthetases composed of one or more modules responsible for the activation and incorporation of specific amino acids into the peptide chain. Genetic analyses of all nonribosomal peptide synthetase systems to date, with the exception of the syringomycin system, have shown them to be arranged in large genomic clusters in which the order and specificity of synthetase modules dictate the peptide sequence (Marahiel et al. 1997; Stein and Vater 1996). Currently, the largest synthetase gene is found in the fungus Tolypocladium niveum, which has a large $45.8-\mathrm{kb}$ open reading frame (ORF) that catalyzes cyclosporin A synthesis (Weber et al. 1994). In P. aeruginosa, the gene cluster responsible for the nonribosomal peptide synthesis of pyoverdine encompasses a $35-\mathrm{kb}$ region of the 6.3-Mb genome (Lehoux et al. 2000), a size typical for prokaryotic synthetase systems (Marahiel et al. 1997; Moffitt and Neilan 2000). The size of syringomycin (syr) and syringopeptin (syp) gene clusters is unknown, but they appear to lie adjacent to one another (Scholz-Schroeder et al. 2001), with the syr cluster representing a minimum DNA region of $35 \mathrm{~kb}$ (Guenzi et al. 1998; Zhang et al. 1995).

Analysis of the $s y r B 1$ and $s y r E$ genes and the $5^{\prime}$ end of the sypA gene indicated that they encode peptide synthetases exhibiting a characteristic modular organization (Guenzi et al. 1998; Scholz-Schroeder et al. 2001; Zhang et al. 1995). Each peptide synthetase module encompasses approximately 1,100 amino acids and is encoded by a DNA region of about $3 \mathrm{~kb}$ (Marahiel et al. 1997; Stein and Vater 1996). Consequently, nine synthetase modules are associated with syringomycin biosynthesis and are encoded by the syrBl and syrE genes; ac- 
cordingly, the syrB1 and syrE ORFs together encompass $30.2 \mathrm{~kb}$ of DNA (Guenzi et al. 1998; Zhang et al. 1995). The syrE ORF alone is $28.4 \mathrm{~kb}$ and represents the largest prokaryotic synthetase gene currently found in the GenBank/EMBL database. In addition to biosynthesis genes, genes involved in secretion (i.e., syrD) (Quigley et al. 1993) and regulation (i.e., syrP) (Zhang et al. 1997) were identified in the syr gene cluster. Using the organization of the syringomycin biosynthetic gene cluster as a model, the syp gene cluster of $P$. syringae pv. syringae strain B301D is predicted to encompass more than $74 \mathrm{~kb}$ of DNA. The $s y r$ and syp gene clusters together likely represent over $100 \mathrm{~kb}$ of DNA on the chromosome of $P$. syringae pv. syringae strain B301D.

It was demonstrated using $s y r B 1$ and sypA synthetase mutants that syringomycin and syringopeptin function as virulence determinants in P. syringae pv. syringae strain B301D (Quigley et al. 1993; Scholz-Schroeder et al. 2001; Xu and Gross 1988a, 1988b; Zhang et al. 1997). Strains carrying mutated synthetase genes were used in virulence studies because they are specifically affected in either syringomycin or syringopeptin biosynthesis. Not only were these synthetase mutants deficient in their ability to produce the respective phytotoxins, but also they were greatly reduced in virulence. In particular, syrB1sypA double mutants failed to produce both syringopeptin and syringomycin and were reduced in virulence by approximately $76 \%$ in immature sweet cherry fruit assays. This provided a definitive measure of the contribution of each of the phytotoxins, individually and in combination, to the plant-pathogen interaction (Scholz-Schroeder et al. 2001).

Clamped homogeneous electric field pulsed-field gel electrophoresis (CHEF-PFGE) is an effective tool for the physical mapping of large regions of bacterial genomes (Fonstein and Haselkorn 1995). This technique was used to construct complete physical maps of the $P$. aeruginosa genome (Ratnaningsih et al. 1990; Römling et al. 1989) and, subsequently, to map the location of virulence-associated genes of $P$. aeruginosa (Shortridge et al. 1991). The syr and syp gene clusters appear to be located adjacent to one another on the chromosome of $P$. syringae pv. syringae strain $\mathrm{B} 301 \mathrm{D}$, based on the recent identification of the sypA synthetase gene at the left border of the $s y r$ gene cluster (Scholz-Schroeder et al. 2001). Preliminary studies suggest that the syr and syp clusters may be localized to a large DraI fragment (approximately $145 \mathrm{~kb}$ ) resolved by CHEF-PFGE (Caponero et al. 1997; Scholz and Gross 1996). In order to define the functional organization of the gene clusters dedicated to the production of the syringomycin and syringopeptin phytotoxins, we constructed a map of this approximately 145-kb DraI fragment by identifying clones from the DraI region, generating a physical map of restriction sites, performing insertional mutagenesis at approximately $15-\mathrm{kb}$ intervals, and performing sequence analysis of sites affected by mutagenesis. Phenotypic effects on toxin production and genotypic data on mutagenized regions were used to delineate the syr and syp gene clusters. Regions carrying genes associated with toxin synthesis, secretion, and regulation were identified, including the map position of the salA regulatory gene that was reported by Kitten and colleagues (1998) to be required for syringomycin production and lesion formation by strain $\mathrm{B} 728 \mathrm{a}$ of $P$. syringae pv. syringae. These results are discussed in regard to the evolution of gene clusters and the relevance to the host-pathogen interaction.

\section{RESULTS}

Syringomycin and syringopeptin genes are located on an approximately 145-kb DraI fragment.

A single DraI fragment, approximately $145 \mathrm{~kb}$, was identified from genomic DNA digests of strain B301D separated by CHEF-PFGE and hybridized with pYM1 (Caponero et al. 1997; Mo and Gross 1991) (Fig. 1), a plasmid carrying a 16-kb HindIII fragment composed of both syr and syp gene sequences (Quigley et al. 1993; Scholz-Schroeder et al. 2001; Zhang et al. 1995, 1997). Using pYM1 in CHEF-PFGE and Southern analysis, two separate DNA fragments, approximately 55 and $90 \mathrm{~kb}$, were identified from genomic DNA of $P$. syringae pv. syringae strain BR334 digested with DraI (Fig. 1). Strain BR334 is an syrC mutant carrying Tn3HoHol insert 334 (Quigley et al. 1993; Zhang et al. 1995), possessing an additional DraI site located in the transposon. Using sypA (pBS008) and syrE (pBS006) probes for hybridization, it was determined that $\operatorname{syr} E$ sequences hybridized to the approximately $55-\mathrm{kb}$ arm and that the sypA sequences hybridized to the approximately $90-\mathrm{kb}$ arm of the DraI fragment (data not shown). Because mini-Tn5 transposons also contain a DraI restriction site, they were used in conjunction with the Tn3HoHol insertion in syrC of strain BR334 to generate a physical map of the approximately 145-kb DraI fragment. In addition to using BR334 carrying the various mini-Tn5 insertions for mapping, these strains served a second purpose. It was observed that Bacillus megaterium was inhibited by the production of large quantities of syringomycin (Lavermicocca et al. 1997) and that sypA mutants of $P$. syringae pv. syringae inhibited the growth of $B$. megaterium (Scholz-Schroeder et al. 2001) due to the production of syringomycin. Therefore, the syringopeptin bioassays were performed on strains of BR334 carrying the various miniTn5 insertions. Because strain BR334 does not produce syringomycin, this provided a clear bioassay for syringopeptin.

\section{Most of the syringomycin gene cluster is located on the approximately $55-\mathrm{kb}$ arm of the DraI fragment.}

Cosmids p149, p634, p29, and p38F2 (Table 1) from a $P$. syringae pv. syringae strain $\mathrm{B} 301 \mathrm{D}$ genomic library hybridized

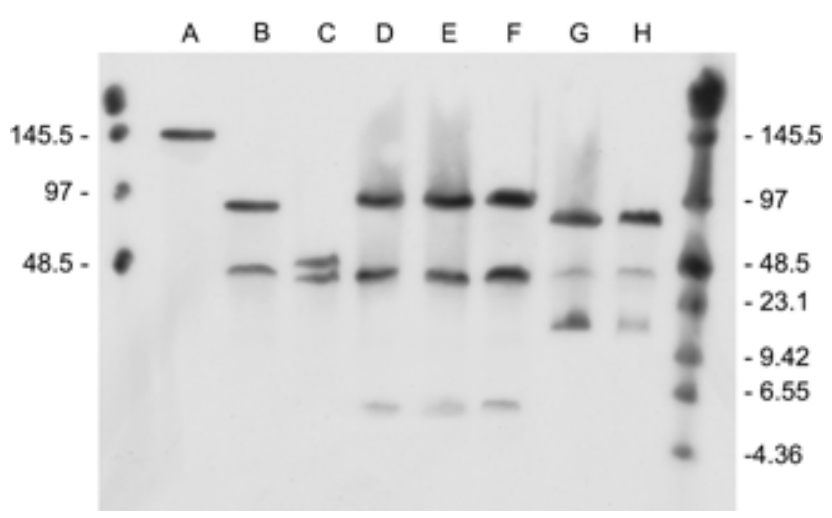

Fig. 1. Autoradiograph of p29, p38F2, p116, p149, and p174 DNA hybridizing to genomic DNA isolated from Pseudomonas syringae pv. syringae strains, digested with DraI, and separated using clamped homogeneous electric field pulsed-field gel electrophoresis. Lane A, B301DR (parental); lane B, BR334 (syrC mutant); lane C, BR334.5; lane D, BR334.1; lane E, BR334.3; lane F, BR334.2; lane G, BR334.5; and lane H, BR334.6. 
to the approximately $55-\mathrm{kb}$ arm of the $\operatorname{DraI}$ fragment from $P$. syringae pv. syringae strain BR334 (data not shown). Restriction maps were constructed for each of the cosmids using DraI, HindIII, EcoRI, and KpnI (Fig. 2). Comparison of the restriction maps combined with Southern hybridization demonstrated that p29 and p634, and pYM1 and p149, carried overlapping DNA (Fig. 2). In addition, p2395, carrying a 13-kb EcoRI fragment with a Tn5 insert isolated from syringomycin mutant strain W4S2395 (Xu and Gross 1988a), was shown to hybridize to the approximately 55-kb arm of the DraI frag- ment and overlap cosmids p29 and p38F2. A subgenomic clone, pBS025, was identified to overlap pYM1 and p38F2. A DraI restriction site was identified in p634 corresponding to the end of the approximately $55-\mathrm{kb}$ arm of the DraI fragment. Cosmids p149, p634, p29, and p38F2 together with plasmids pYM1, p2395, and pBS025 encompass the entire approximately $55-\mathrm{kb}$ arm of the approximately $145-\mathrm{kb}$ DraI fragment.

Several regions along the approximately $55-\mathrm{kb}$ arm were subsequently subcloned, mutagenized, and recombined back into the genome of strains B301D and BR334 for genotypic

Table 1. Bacterial strains and plasmids

\begin{tabular}{|c|c|c|}
\hline Strain or plasmid & Relevant characteristics $^{\mathbf{a}}$ & Source \\
\hline \multicolumn{3}{|c|}{ Pseudomonas syringae pv. syringae } \\
\hline B301D & Wild type from pear & Cody et. al. 1987 \\
\hline B301DR & Spontaneous Rif ${ }^{\mathrm{r}}$ derivative of B301D & $\mathrm{Xu}$ and Gross $1988 \mathrm{~b}$ \\
\hline BR334 & syrC::Tn3HoHo1 derivative of B301DR; Pip $^{\mathrm{r}}$ Rif $^{\mathrm{r}}$ & Quigley et al. 1993 \\
\hline B301D.1 & mini-Tn5 derivative of B301D from pBS042Km; Km ${ }^{\mathrm{r}}$ & This study \\
\hline B301D.2 & mini-Tn5 derivative of B301D from pBS044Km; Km ${ }^{\mathrm{r}}$ & This study \\
\hline B301D.3 & mini-Tn5 derivative of B301D from pSL008Km; $\mathrm{Km}^{\mathrm{r}}$ & This study \\
\hline B301D.4 & mini-Tn5 derivative of B301D from pJS013Km; Km ${ }^{\mathrm{r}}$ & This study \\
\hline B301D.5 & mini-Tn5 derivative of B301D from pJS049Km; $\mathrm{Km}^{\mathrm{r}}$ & This study \\
\hline B301D.6 & mini-Tn5 derivative of B301D from pJS055Km; $\mathrm{Km}^{\mathrm{r}}$ & This study \\
\hline BR334.1 & mini-Tn5 derivative of BR334 from pBS042Km; Km ${ }^{\mathrm{r}}$ Pip $^{\mathrm{r}}$ Rif $^{\mathrm{r}}$ & This study \\
\hline BR334.2 & mini-Tn5 derivative of BR334 from pBS044Km; Km ${ }^{\mathrm{r}} \mathrm{Pip}^{\mathrm{r}} \mathrm{Rif}^{\mathrm{r}}$ & This study \\
\hline BR334.3 & mini-Tn5 derivative of BR334 from pSL008Km; Km ${ }^{\mathrm{r}}$ Pip $^{\mathrm{r}} \mathrm{Rif}^{\mathrm{r}}$ & This study \\
\hline BR334.4 & mini-Tn5 derivative of BR334 from pJS013Km; Km ${ }^{\mathrm{r}}$ Pip $^{\mathrm{r}}$ Rif $^{\mathrm{r}}$ & This study \\
\hline BR334.5 & mini-Tn5 derivative of BR334 from pJS049Km; Km ${ }^{\mathrm{r}}$ Pip $^{\mathrm{r}} \mathrm{Rif}^{\mathrm{r}}$ & This study \\
\hline BR334.6 & mini-Tn5 derivative of BR334 from pJS055Km; Km ${ }^{\mathrm{r}}$ Pip $^{\mathrm{r}} \mathrm{Rif}^{\mathrm{r}}$ & This study \\
\hline \multicolumn{3}{|l|}{ Escherichia coli } \\
\hline DH10B & $\begin{array}{l}\mathrm{F}^{-} \text {mcrA } \Delta l a c \mathrm{X} 74(\phi 80 \mathrm{~d} l a c \mathrm{Z} \Delta \mathrm{M} 15) \Delta(\mathrm{mrr}-h s d \mathrm{RMS}-m c r \mathrm{~B}) \text { deo } \mathrm{R} \text { rec } \mathrm{A} 1 \text { end } \mathrm{A} 1 \\
\quad \text { araD139 } \Delta(\text { ara, leu }) 7697 \text { gal } \mathrm{U} \text { gal } \mathrm{K} \lambda^{-} \text {rps } \mathrm{L} \text { nu } \mathrm{G}\end{array}$ & Hanahan 1985 \\
\hline XL1-Blue MR & rec $\mathrm{A} 1$ end $\mathrm{A} 1$ gyrA96 thi-1 hsdR17 sup $\mathrm{E} 44 \operatorname{rel} \mathrm{A} 1\left[\mathrm{~F}^{\prime}\right.$ pro $\mathrm{AB}$ lac $\left.\mathrm{I}^{\mathrm{q}} \mathrm{Z} \Delta \mathrm{M} 15 \operatorname{Tn} 10\left(\mathrm{Tet}^{\mathrm{r}}\right)\right]$ & Stratagene, La Jolla, CA, U.S.A. \\
\hline \multicolumn{3}{|l|}{ Plasmids } \\
\hline pBluescript II SK & High-copy-number cloning vector; $\mathrm{Ap}^{\mathrm{r}}$ & Stratagene \\
\hline pUC18 & High-copy-number cloning vector; $\mathrm{Ap}^{\mathrm{r}}$ & Yanisch-Perron et al. 1985 \\
\hline pUTKm & Delivery plasmid for mini-Tn $5 \mathrm{Km} ; \mathrm{Km}^{\mathrm{r}}$ & Herrero et al. 1990 \\
\hline pBR325 & Low-copy-number plasmid for marker exchange; $\mathrm{Tc}^{\mathrm{r}}$ & Prentki et al. 1981 \\
\hline pLAFR3 & IncP $\cos ^{+} \mathrm{rlx}^{+} ; \mathrm{Tc}^{\mathrm{r}}$ & Staskawicz et al. 1987 \\
\hline pYM1 & pGS72 carrying a 16-kb HindIII fragment from strain B301D; $\mathrm{Tc}^{\mathrm{r}}$ & Mo and Gross 1991 \\
\hline pBS006 & pUC18 carrying a $3-\mathrm{kb}$ BamHI fragment of p38F2; $\mathrm{Ap}^{\mathrm{r}}$ & This study \\
\hline pBS008 & pUC18 carrying a 5.1-kb EcoRI-KpnI fragment of pYM1; $\mathrm{Ap}^{\mathrm{r}}$ & Scholz-Schroeder et al. 2001 \\
\hline p2395 & pBR325 carrying $13-\mathrm{kb}$ P. syringae pv. syringae strain B301D genomic DNA; Tc ${ }^{\mathrm{r}}$ & D. C. Gross, personal communication \\
\hline pJS013 & pBSK carrying a 7.8-kb EcoRI fragment of p753; $\mathrm{Ap}^{\mathrm{r}}$ & This study \\
\hline pJS049 & pBSK carrying an $8.1-\mathrm{kb}$ Bam HI fragment of $\mathrm{p} 174 ; \mathrm{Ap}^{\mathrm{r}}$ & This study \\
\hline pJS055 & pBSK carrying a 2.1-kb HindIII fragment of p116; Ap ${ }^{\mathrm{r}}$ & This study \\
\hline pJS013Km & pJS013 with mini-Tn5 inserted into BstZ17 site moved to $\mathrm{pBR} 325 ; \mathrm{Km}^{\mathrm{r}} \mathrm{Tc}^{\mathrm{r}}$ & This study \\
\hline pJS049Km & pJS049 with mini-Tn5 inserted into NsiI site moved to pBR325; $\mathrm{Km}^{\mathrm{r}} \mathrm{Tc}^{\mathrm{r}}$ & This study \\
\hline pJS055Km & pJS055 with mini-Tn5 inserted into BstEII site moved to pBR325; $\mathrm{Km}^{\mathrm{r}} \mathrm{Tc}^{\mathrm{r}}$ & This study \\
\hline pBS042 & pUC18 carrying a $3.0-\mathrm{kb}$ Bam HI fragment of p38F2; Ap ${ }^{\mathrm{r}}$ & This study \\
\hline pBS044 & pUC18 carrying a 3.2-kb EcoRI/HindIII fragment of p2395; Ap ${ }^{\mathrm{r}}$ & This study \\
\hline pBS042Km & pBS042 with mini-Tn5 inserted into NsiI site moved to pBR325; $\mathrm{Km}^{\mathrm{r}} \mathrm{Tc}^{\mathrm{r}}$ & This study \\
\hline pBS044Km & pBS014 with mini-Tn5 inserted into BpoI site moved to pBR325; $\mathrm{Km}^{\mathrm{r}} \mathrm{Tc}^{\mathrm{r}}$ & This study \\
\hline pSL008 & pBR325 carrying a 3.0-kb EcoRI fragment of p29; $\mathrm{Tc}^{\mathrm{r}}$ & This study \\
\hline pSL008Km & pSL008 with mini-Tn5 inserted into $K p n I$ site moved to pBR325; $\mathrm{Km}^{\mathrm{r}} \mathrm{Tc}^{\mathrm{r}}$ & This study \\
\hline pJS091 & pBSK carrying a 4.7-kb HindIII fragment from strain B301D; Ap ${ }^{\mathrm{r}}$ & This study \\
\hline pBS025 & pUC18 carrying a $12-\mathrm{kb}$ BamHI/EcoRI fragment from strain B301D; $\mathrm{Ap}^{\mathrm{r}}$ & This study \\
\hline pJS115 & pBSK carrying an 8.4-kb KpnI fragment from strain B301D; $\mathrm{Ap}^{\mathrm{r}}$ & This study \\
\hline \multicolumn{3}{|l|}{ Cosmids } \\
\hline p29 & pLAFR3 carrying a 16-kb $P$. syringae pv. syringae strain B301D genomic DNA fragment; Tc ${ }^{\mathrm{r}}$ & This study \\
\hline p38F2 & pLAFR3 carrying a 19-kb $P$. syringae pv. syringae strain B301D genomic DNA fragment; Tc ${ }^{\mathrm{r}}$ & This study \\
\hline p27B5 & pLAFR3 carrying a 20-kb $P$. syringae pv. syringae strain B301D genomic DNA fragment; Tc ${ }^{\mathrm{r}}$ & This study \\
\hline p116 & pLAFR3 carrying a $20-\mathrm{kb} P$. syringae pv. syringae strain B301D genomic DNA fragment; Tc ${ }^{\mathrm{r}}$ & This study \\
\hline p149 & pLAFR3 carrying a 30-kb P. syringae pv. syringae strain B301D genomic DNA fragment; Tc ${ }^{\mathrm{r}}$ & This study \\
\hline p174 & pLAFR3 carrying a 23-kb $P$. syringae pv. syringae strain B301D genomic DNA fragment; $\mathrm{Tc}^{\mathrm{r}}$ & This study \\
\hline p634 & pLAFR3 carrying a 24-kb $P$. syringae pv. syringae strain B301D genomic DNA fragment; Tc ${ }^{\mathrm{r}}$ & This study \\
\hline p753 & pLAFR3 carrying an 8-kb $P$. syringae pv. syringae strain B301D genomic DNA fragment; Tc ${ }^{\mathrm{r}}$ & This study \\
\hline
\end{tabular}

${ }^{\mathrm{a}} \mathrm{Ap}^{\mathrm{r}}, \mathrm{Km}^{\mathrm{r}}, \mathrm{Pip}^{\mathrm{r}}, \mathrm{Tc}^{\mathrm{r}}$, and $\mathrm{Rif}^{\mathrm{r}}=$ resistance to ampicillin, kanamycin, piperacillin, tetracycline, and rifampicin, respectively. 
and phenotypic analyses. Restriction fragments were chosen for subcloning from p38F2, p2395, and p29. Site-directed mutagenesis of these subclones generated the constructs pBS042Km, pBS044Km, and pSL008Km carrying mini-Tn5 insertions (Tables 1 and 2). Strains B301D.1, B301D.2, and B301D.3 (Tables 1 and 2), as well as strains BR334.1, BR334.2, and BR334.3 (Tables 1 and 2), were obtained by marker exchange of homologous DNA carried on plasmids pBS042Km, pBS044Km, and pSL008Km, respectively, into strains B301D and BR334. CHEF-PFGE mapping of strains BR334.1, BR334.2, and BR334.3 established that the insertions are located approximately $5 \mathrm{~kb}$, approximately $25 \mathrm{~kb}$, and approximately $45 \mathrm{~kb}$ from the Tn3HoHol insert 334 and were designated mini-Tn5 insertions 1,2 , and 3 (Fig. 2). It was determined that strains carrying mini-Tn5 insertions 1,2 , and 3 failed to produce syringomycin in bioassays as they did not inhibit Geotrichum candidum. Nevertheless, strains carrying mini-Tn 5 insertions 1 and 2 produced syringopeptin, based on the production of typical zones of inhibition ( 8 to $10 \mathrm{~mm}$ in radius) to $B$. megaterium. Strain B301D.3 produced $34 \%$ less syringopeptin as compared with strain B301D. Finally, wildtype levels of inhibition were observed for B301D.3 complemented in trans with the parental cosmid p29. Because the entire $s y r E$ gene is not carried on a plasmid, wild-type levels of inhibition were not observed for B301D.1 and B301D.2 complemented in trans with the parental cosmids p38F2 and p29, respectively.

Sequence analysis of 500 bases upstream and downstream of the mini-Tn5 insertions carried on pBS042Km and pBS044Km demonstrated that mini-Tn5 insertions 1 and 2 were located within the $s y r E$ gene (GenBank/EMBL accession no. AF047828) at nucleotides 4,112 and 23,737 , respectively (Table 2, Fig. 2). Consequently, mini-Tn5 insertions 1 and 2 are located in $s y r E$ regions encoding modules 2 (serine) and 8 (3-hydroxy aspartic acid) of the SyrE synthetase (Guenzi et al. 1998). Sequence analysis of the Tn5 insert carried on plasmid p2395 determined that it is located at nucleotide 27,295 of syrE, right at the beginning of the terminal thioesterase do-

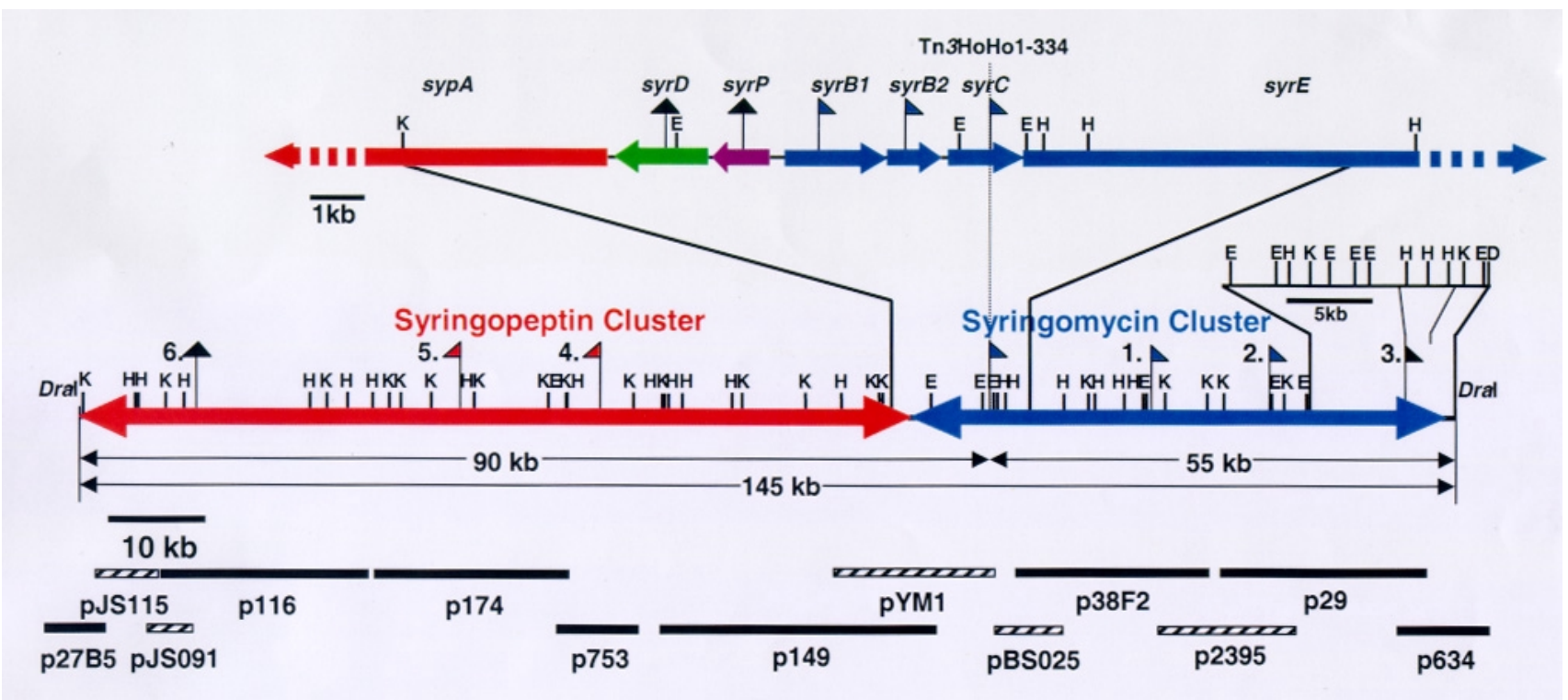

Fig. 2. Diagrammatic representation of the approximately 145-kb DraI fragment of Pseudomonas syringae pv. syringae strain B301D. The syringopeptin (red arrow) and syringomycin (blue arrow) gene clusters are presented with their relative location on the approximately $145-\mathrm{kb}$ DraI fragment. The position and orientation of the $\operatorname{syr} D, \operatorname{syr} P, \operatorname{syrB1}, \operatorname{syrB2}, \operatorname{syr} C, \operatorname{syrE}$, and $\operatorname{syp} A$ genes as organized on the $P$. syringae pv. syringae B301D chromosome are inset above the map of the approximately 145-kb DraI fragment. The placement of the cosmids and subgenomic clones along the DraI fragment are indicated below the map as solid black and diagonally hatched lines, respectively. The position of the Tn3HoHo1 insert 334 located within $\operatorname{syrC}$ is designated with a horizontal dotted line. Vertical arrows numbered 1 through 6 indicate the positions of the mini-Tn5 insertions used to map the DraI fragment. The phenotypic results of insertions along the 145-kb DraI fragment are designated with a blue flag pointed right for loss of syringomycin production; a red flag pointed left for loss of syringopeptin production; and a double-sided black flag for loss of syringomycin and syringopeptin production. The restriction enzyme sites for EcoRI (E), HindIII (H), KpnI (K), and $\operatorname{DraI}$ are identified.

Table 2. Evaluation of the mini-Tn5 insertions in Pseudomonas syringae pv. syringae strain B310D, resultant phenotypes, and sequence analysis of the flanking DNA sequence

\begin{tabular}{|c|c|c|c|c|c|}
\hline \multirow[b]{2}{*}{ Strain } & \multicolumn{2}{|c|}{ Phenotype } & \multirow[b]{2}{*}{ Plasmid } & \multirow[b]{2}{*}{ Sequence homology ${ }^{a}$} & \multirow[b]{2}{*}{$Z$ score } \\
\hline & Syringomycin & Syringopeptin & & & \\
\hline B301D.1 & - & + & $\mathrm{pBS} 042 \mathrm{Km}$ & syrE & 422.6 \\
\hline B301D.2 & - & + & pBS044Km & syrE & 324.1 \\
\hline B301D.3 & - & + & pSL008Km & salA & 220.1 \\
\hline B301D.4 & + & - & pJS013Km & syrE & 263.2 \\
\hline B301D.5 & + & - & pJS049Km & syrE & 249.9 \\
\hline B301D.6 & - & - & pJS055Km & $y b j Z$ & 233.0 \\
\hline
\end{tabular}

${ }^{a}$ Nucleotide sequence data are available in the GenBank/EMBL databases under the accession numbers AF047828 for syrE, AF022808 for salA, and AE000198 for $y b j Z$. 
main of the SyrE synthetase (Guenzi et al. 1998). It was also determined that the mini-Tn5 insertion 3, carried on pSL008Km, is located at nucleotide 686 within the salA gene (GenBank/ EMBL accession no. AF022808) (Kitten et al. 1998) (Table 2 ). The salA gene was originally described from $P$. syringae pv. syringae strain B728a, and we estimate it to be located approximately $8 \mathrm{~kb}$ downstream of the $s y r E$ synthetase gene in strain B301D. Six nucleotide differences were observed after comparison of the last 669 nucleotides (Kitten et al. 1998) obtained from the salA gene from strain B301D with the corresponding 669 nucleotides of the salA gene from strain B728a. Furthermore, a single amino acid difference was observed by comparison of the putative SalA amino acid sequence of strain B301D to the analogous sequence of SalA from strain B728a (Kitten et al. 1998).

\section{The syringopeptin gene cluster is located on the approximately $\mathbf{9 0 - k b}$ arm of the DraI fragment.}

Four cosmids, p149, p753, p174, and p116, isolated from a $P$. syringae pv. syringae strain B301D genomic library hybridized to the original approximately $145-\mathrm{kb}$ DraI fragment and to the approximately $90-\mathrm{kb}$ DraI fragment in strain BR334 (data not shown). Cosmids were mapped by restriction analysis using DraI, HindIII, EcoRI, and KpnI (Fig. 2). Southern hybridization identified overlaps that were present between p149 and pYM1, as well as between p753 and p174. Chromosomal walking using p116 sequences as a hybridization probe identified strain B301D genomic subclone pJS091 (Fig. 2, Table 1). Repeating this step, using pJS091 as a hybridization probe, genomic subclone pJS115 of strain B301D was identified (Fig. 2, Table 1). Using pJS115 as a hybridization probe, cosmid p27B5 was identified from the genomic library. These cosmids and plasmids were mapped by restriction analysis using DraI, HindIII, EcoRI, and KpnI (Fig. 2). A DraI restriction site was identified in cosmid p27B5, demonstrating that it carried sequences located at the end of the approximately $90-\mathrm{kb}$ arm of the approximately 145-kb DraI fragment.

In order to map the approximately $90-\mathrm{kb}$ arm of the DraI fragment, regions were chosen from the various cosmids and plasmids spanning the region for subcloning and mutagenesis. Restriction fragments were chosen for subcloning from $\mathrm{p} 753$, p174, and p116 and mutagenized by the site-specific introduction of mini-Tn5 insertions to construct plasmids pJS013Km, pJS049Km, and pJS055Km, respectively (Table 1). Strains B301D.4, B301D.5, and B301D.6, as well as BR334.4, BR334.5, and BR334.6, were generated by homologous recombination of the mutagenized fragments carried on plasmids pJS013Km, pJS049Km, and pJS055Km, respectively, into strains B301D and BR334, generating mini-Tn5 insertions 4, 5, and 6 (Fig. 2). CHEF-PFGE and Southern analysis indicated that the mini-Tn 5 insertions 4,5 , and 6 mapped approximately 40, 50, and $85 \mathrm{~kb}$, respectively, from Tn $3 \mathrm{HoHo} 1$ insert 334 (Fig. 2).

To further characterize mini-Tn5 insertions 4,5 , and 6 , the respective strains carrying the insertions were analyzed in phytotoxin bioassays and the insertions were sequenced. Strains carrying mini-Tn5 insertions 4 and 5 produced wildtype amounts of syringomycin, based on inhibition of G. candidum growth; however, no syringomycin production was detected for strains carrying mini-Tn5 insertion 6 . In contrast, strains carrying mini-Tn5 insertions 4,5 , and 6 did not pro- duce zones of inhibition against $B$. megaterium, which indicates a lack of syringopeptin production (data not shown). Wild-type levels of inhibition were observed for B301D.6 complemented in trans with the parental cosmid p116. In addition, it is hypothesized that the syp gene(s) could be as large as $\operatorname{syrE}(28.4 \mathrm{~kb})$ and it is not expected that an entire syp gene would be located on a single cosmid from a genomic library. Therefore, as expected, wild-type levels of inhibition were not observed for B301D.4 and B301D.5 complemented in trans with the parental cosmids p753 and p174, respectively. Sequence analysis of DNA flanking the mini-Tn5 insertions 4 and 5 identified sequences encoding peptide synthetases. BLAST analysis demonstrated that the putative protein products are homologous to SyrE (GenBank/EMBL accession no. AF047828) (Table 2). BLAST analysis of the DNA flanking mini-Tn5 insertion 6 indicated that it is located within a gene encoding a protein with homology to YbjZ (GenBank/EMBL accession no. AE000189), an ABC transporter (Blattner et al. 1997) (Table 2). Mini-Tn5 insertion 6 apparently disrupts a gene whose putative protein product may be involved in the secretion of both phytotoxins.

\section{DISCUSSION}

Two nonribosomal peptide synthetase systems, the $s y r$ and syp biosynthetic gene clusters, were localized to an approximately 145-kb DraI fragment. Phenotypic and genotypic analyses of this DraI fragment identified important aspects unique to phytotoxin production by $P$. syringae pv. syringae: (i) the syr and syp biosynthetic clusters are distinct and located adjacent to each other on the B301D chromosome; (ii) a minimum of $66 \%$ of the DraI fragment encodes peptide synthetases responsible for syringomycin and syringopeptin biosynthesis; (iii) genes involved in the regulation (e.g., salA) and secretion (e.g., ABC transporter homolog) of syringomycin and syringopeptin are located at the right and left border regions of the clusters, respectively; and (iv) the $s y r$ and syp gene clusters account for $93 \%$ of the DraI fragment and, therefore, comprise approximately $2 \%$ of the $P$. syringae pv. syringae genome (based on a genome size range of 3.7 to $7.1 \mathrm{Mb}$ for Pseudomonas species [Spiers et al. 2000; Stover et al. 2000]). The syr and syp gene clusters combined are the largest known DNA region dedicated to nonribosomal peptide synthetase systems in a microorganism, and they appear to constitute a genomic island (Hacker and Kaper 2000) of approximately $135 \mathrm{~kb}$ in P. syringae pv. syringae.

The syp gene cluster and nearly the entire syr gene cluster are located on the approximately $145-\mathrm{kb}$ DraI fragment. The syp gene cluster encompasses approximately $80 \mathrm{~kb}$ of DNA, and approximately $70 \mathrm{~kb}$ of DNA from this region is dedicated to encoding peptide synthetases. In addition, mutations located in regions coding for peptide synthetases disrupted either syringomycin or syringopeptin production. This indicates that syringomycin and syringopeptin are synthesized by separate nonribosomal peptide synthetase systems. There are several nonribosomal peptide synthetase systems in which large gene clusters are responsible for the synthesis of a peptide. The largest peptide synthetase, CYSYN, is encoded by the 45.8-kb $\operatorname{sim} A$ gene (Weber et al. 1994). CYSYN is responsible for the activation and incorporation of 11 amino acids during the nonribosomal synthesis of cyclosporin A in the fungus $T$. 
niveum. In addition, a $35-\mathrm{kb}$ gene cluster containing several peptide synthetase genes was also identified in $P$. aeruginosa (Lehoux et al. 2000). This gene cluster is responsible for the nonribosomal peptide synthesis of pyoverdine, resulting in the incorporation of eight amino acids into the peptide structure. It was previously reported that the syr gene cluster was located on the large arm of the approximately 145-kb DraI fragment (Caponero et al. 1997). Considering the facts that sypA gene sequences hybridize to the large arm of the DraI fragment and that insertions 5 and 6 map to the large arm of the DraI fragment and specifically disrupt syringopeptin production, it is evident that the syr gene cluster is located on the small arm of the approximately $145-\mathrm{kb}$ DraI fragment. However, it was determined that the syr gene cluster phenotypically extends to, and may extend past, the DraI site. Consequently, the syr gene cluster currently encompasses approximately $55 \mathrm{~kb}$ of DNA, $30.2 \mathrm{~kb}$ of which is dedicated to encoding syringomycin peptide synthetases (Guenzi et al. 1998). The syr and syp gene clusters were phenotypically delineated to encompass approximately $135 \mathrm{~kb}$ of DNA, and it is evident that a great proportion of the cluster (approximately 78\%) is dedicated to phytotoxin biosynthesis.

Peptide synthetases contain conserved, repetitive modules composed of condensation, amino acid activation, and thiolation domains (Marahiel et al. 1997). Approximately $3 \mathrm{~kb}$ of DNA is required to encode a module, and a separate module is required for the addition of each amino acid to the peptide. Contiguous cosmids and plasmids were not identified that encompassed the entire large arm of the DraI fragment (Fig. 2). However, the DNA encoding the first module of syringopeptin biosynthesis, SypA-M1, previously sequenced and analyzed (Scholz-Schroeder et al. 2001), were mapped to the large arm of the DraI fragment. The conserved structure of peptide synthetases (Marahiel et al. 1997), in conjunction with the CHEFPFGE data, enabled estimations to be made with regard to the map of the syp gene cluster (Fig. 2). The current physical map of the syp gene cluster accounts for the physical distance required for syringopeptin biosynthesis and supports the biosynthesis of syringopeptin by nonribosomal peptide synthetases (Grgurina and Benincasa 1994; Scholz-Schroeder et al. 2001).

The right border of the $s y r$ gene cluster contains genes that strongly affect syringomycin production. The most prominent observation of this region was the mapping of the salA gene to the $s y r$ gene cluster near the end of the approximately $145-\mathrm{kb}$ DraI fragment. The salA gene was originally described by Kitten and colleagues (1998) from $P$. syringae pv. syringae strain B728a to have an important role in the plant-pathogen interaction. The salA gene is a component of the gacA/gacS regulon that regulates both syringomycin production and the ability to form lesions on bean leaves (Kitten et al. 1998). Although this gene was functionally linked to syringomycin production, its location relative to the $s y r$ gene cluster was undefined. Here, we report that it is located approximately $10 \mathrm{~kb}$ from the end of the DraI fragment and approximately $8 \mathrm{~kb}$ from the end of syrE. In addition, we found the salA gene sequence attained from $P$. syringae pv. syringae strain B301D to be essentially identical to that of strain B728a. The salA gene is the second regulatory gene identified within the $s y r$ gene cluster to have a role in the production of syringomycin. The syrP gene, located between the syrBl and $s y r D$ genes, was previously shown to have an effect on syringomycin produc- tion in response to phosphate levels (Zhang et al. 1997). The SyrP protein exhibits homology to proteins such as CheA and KinA that are regulatory elements in phosphorelay pathways. The identification of a second regulatory gene suggests that there are multiple levels of regulation for syringomycin. In addition, it is evident that the regulation of syringomycin and syringopeptin is separate. The identification of the salA gene within the syr gene cluster suggests that genes other than peptide synthetases have an important role in the production of syringomycin by $P$. syringae pv. syringae strain B301D.

The left border of the syp gene cluster contains a gene that may affect the secretion of both syringomycin and syringopeptin. A putative ABC transporter homolog is located within the syp cluster about $10 \mathrm{~kb}$ from the DraI restriction site. Mutagenesis of this region results in the loss of syringopeptin and syringomycin production. This phenotype is similar to a previously identified ABC transporter homolog, SyrD (Quigley et al. 1993), which is responsible for the secretion of both syringomycin and syringopeptin (Grgurina et al. 1996). It is apparent that the syp and syr clusters are phenotypically linked with regard to the secretion of the two toxins, even though $s y r D$ and the newly identified putative ABC transporter homolog are physically separated by more than $75 \mathrm{~kb}$ of DNA. The P. aeruginosa genome contains many (>20) currently undescribed efflux systems including $\mathrm{ABC}$ transporters (Stover et al. 2000), and it was suggested that efflux systems could have wide-ranging specificity and be responsible for the secretion of multiple substrates (Van Bambeke et al. 2000). It is possible that there are two or more separate secretion systems responsible for the secretion of both syringomycin and syringopeptin.

The concept of genome evolution and how gene clusters contribute to the adaptive fitness of an organism is the focus of intense discussion and debate (Hacker and Kaper 2000; Lawrence and Roth 1996). Hacker and Kaper (2000) described genomic islands as large contiguous DNA regions (10 to $200 \mathrm{~kb}$ ) whose gene products contribute to the adaptation and fitness of both pathogenic and nonpathogenic bacterial strains. These genomic islands may or may not contain characteristic features of pathogenicity islands, and pathogenicity islands themselves are a subset of genomic islands. The approximately $135 \mathrm{~kb}$ of DNA encompassed by the syr and syp gene clusters accounts for about $2 \%$ of the $P$. syringae pv. syringae strain B301D genome (based on a genome size of $6.26 \mathrm{Mb}$ for the $P$. aeruginosa PA01 genome [Stover et al. 2000]). In addition, the production of syringomycin and syringopeptin is a stable phenotype for $P$. syringae pv. syringae strain B301D (Quigley and Gross 1994). However, using pYM1 carrying syr and syp gene sequences as a hybridization probe (Fig. 2), it was demonstrated that this region is unstable in $P$. syringae pv. syringae strain B728a (Rich and Willis 1997). In addition, the syr and syp gene clusters are not present in other pathovars of P. syringae (Quigley and Gross 1994). The presence of the syr-syp gene clusters may be the result of a macroevolutionary process leading to $P$. syringae pv. syringae and other closely related pathovars producing lipodepsipeptide phytotoxins (Hacker and Kaper 2000). It is evident from this analysis of $P$. syringae pv. syringae mutants (Quigley et al. 1993; Xu and Gross 1988b; Zhang et al. 1995) that disruption of one or both of the toxins can occur by mutagenesis in numerous places along the approximately 145-kb DraI fragment, suggesting that strict 
conservation of the DNA sequence in the syr-syp cluster is necessary for the production of both phytotoxins in $P$. syringae pv. syringae. It was previously demonstrated that both syringomycin and syringopeptin together contribute extensively to the virulence of the $P$. syringae pv. syringae strain B301D, with virulence of syrB1-sypA double mutants reduced by approximately $76 \%$ in immature sweet cherry fruit assays (ScholzSchroeder et al. 2001). While it is evident they function as virulence determinants, it is unclear what other roles, if any, these phytotoxins may play in the fitness of $P$. syringae pv. syringae. Consequently, it appears that the syr-syp gene clusters may represent a genomic island (Hacker and Kaper 2000).

This is not the first report of a genomic island within $P$. syringae pv. syringae. The Hrp pathogenicity island of $P$. syringae pv. syringae is composed of the hrp/hrc gene cluster flanked by the exchangeable effector locus and the conserved effector locus (Alfano et al. 2000). Together, the tripartite pathogenicity island, a subset of a genomic island (Hacker and Kaper 2000), contributes to the pathogenicity and parasitic fitness of $P$. syringae pv. syringae. Recently, Lawrence and Roth (1996) described a model for the transfer of gene clusters that contribute to the fitness of the organism and designated them selfish operons. A conceptual picture of the syr and syp gene clusters is developing, and it may become evident that they are genomic islands and may function as selfish operons.

Genotypic and phenotypic analyses of the 145-kb DraI fragment carrying the syr and syp gene clusters provide a valuable foundation for the analysis of syringomycin and syringopeptin production in $P$. syringae pv. syringae strain B301D. The delineation of the syringopeptin biosynthetic region helps facilitate sequencing of this region and the identification of gene(s) involved in syringopeptin biosynthesis. In addition to genes coding for peptide synthetases, it would be expected that there may be genes coding for epimerization of amino acids within the peptide structure, as well as acyl-transferase activity responsible for the attachment of the fatty acid tail to the peptide (Marahiel et al. 1997). The demarcation of the syr and syp gene clusters and their constituents as a genomic island continues to further our understanding of the role of the syr and syp gene clusters not only to the biology of the organism, but also to the evolutionary development of $P$. $s y$ ringae pv. syringae.

\section{MATERIALS AND METHODS}

Bacterial strains, plasmids, media, and growth conditions.

Bacterial strains and plasmids are listed in Table 1. P. syringae pv. syringae strains were routinely cultured at $25^{\circ} \mathrm{C}$ in nutrient broth yeast extract (NBY) liquid or agar media (Vidaver 1967). Escherichia coli strains DH10B (Gibco-BRL Life Technologies, Inc., Grand Island, NY, U.S.A.) and XL1-Blue MR (Stratagene, La Jolla, CA, U.S.A.) were cultured at $37^{\circ} \mathrm{C}$ in Luria Bertani (LB) broth or agar (Sambrook et al. 1989). Syringomycin bioassays were performed on potato dextrose agar (PDA) supplemented with $0.4 \%$ casamino acids and $1.5 \%$ glucose (20 ml per plate) (Gross and DeVay 1977). The syringopeptin bioassays were performed on peptone-glucose$\mathrm{NaCl}$ agar (PGNA) containing $5 \mathrm{~g}$ of peptone, $10 \mathrm{~g}$ of glucose, $5 \mathrm{~g}$ of $\mathrm{NaCl}$, and $8 \mathrm{~g}$ of agar $(20 \mathrm{ml}$ per plate) (Bultreys and Gheysen 1999). Antibiotics (Sigma Chemical Co., St. Louis) were added as required to media using the following final con- centrations: ampicillin, $100 \mu \mathrm{g} / \mathrm{ml}$; tetracycline, $25 \mu \mathrm{g} / \mathrm{ml}$; piperacillin, $25 \mu \mathrm{g} / \mathrm{ml}$; and kanamycin, $100 \mu \mathrm{g} / \mathrm{ml}$.

\section{Bioassay for syringomycin and syringopeptin production by $P$. syringae pv. syringae strains.}

Each of the $P$. syringae pv. syringae strains used in this study was screened for the ability to produce syringomycin and syringopeptin using the PDA and PGNA plate bioassays described by Scholz-Schroeder and colleagues (2001). Briefly, $P$. syringae pv. syringae strains were grown overnight in $5 \mathrm{ml}$ of NBY liquid medium. Bacterial cells were harvested by centrifugation and washed once with sterile distilled water (SDW). The cells were resuspended in SDW to an optical density of 0.3 (approximately $2 \times 10^{8} \mathrm{CFU} / \mathrm{ml}$ ), and 5- $\mu \mathrm{l}$ aliquots of bacterial suspension were spotted onto PDA and PGNA plates. The plates were incubated for 3 days at $25^{\circ} \mathrm{C}$, and PDA plates were oversprayed lightly with an arthrospore suspension of the bioassay fungus, G. candidum F-260, whereas PGNA plates were oversprayed with a cell suspension of B. megaterium strain Km (Grgurina et al. 1996; Lavermicocca et al. 1997). The $P$. syringae pv. syringae mutant strains were compared with the parental strain for the formation of zones of fungal and bacterial inhibition. To avoid confusion in distinguishing between syringomycin and syringopeptin zones of inhibition, mutations were introduced into strains B301D and BR334 (Zhang et al. 1995). Strain BR344 is a syringomycin syrC mutant of B301DR that produces large amounts of syringopeptin (Grgurina et al. 1996), which allows for a distinct bioassay for syringopeptin.

\section{DNA manipulations and sequence analysis.}

Plasmid DNA were isolated using a cetyltrimethylammonium bromide boiling plasmid preparation (Del Sal et al. 1989). Routine procedures (Ausubel et al. 1990; Sambrook et al. 1989) were used for cosmid and genomic DNA isolation, restriction endonuclease digestions, and subcloning.

Sequencing primers were synthesized by Operon Technologies, Inc. (Alameda, CA, U.S.A.). Sequence reactions were completed for both strands using fluorescence-based dideoxy terminators and Ampli-Taq polymerase (Perkin-Elmer Applied Biosystems, Inc., Norwalk, CT, U.S.A.). Sequence reactions were run on an ABIPRISM 377 DNA sequencer (PerkinElmer Applied Biosystems, Inc.). Sequence data were analyzed using the Wisconsin Sequence Analysis programs of the Genetic Computer Group (GCG) (release beta 10.0; Genetic Computer Group, Inc., Madison, WI, U.S.A.) (Devereux et al. 1984). The program NETBLAST (Altschul et al. 1990) was used to identify nucleic acid and protein homologies. The program BESTFIT was used for the comparison of two protein sequences and Z-score calculations. The BESTFIT program was run using the randomization option of 100 to produce the data necessary for $Z$-score calculations. The $Z$ score was calculated using the actual quality score minus the mean quality value of the randomized scores divided by the standard deviation of randomized score distribution. $Z$ scores greater than six were considered significant.

\section{Cosmid library construction.}

Chromosomal DNA from $P$. syringae pv. syringae strain B301D were prepared using standard techniques (Ausubel et al. 1990; Sambrook et al. 1989). The chromosomal DNA were 
partially cleaved using Sau3A (Gibco-BRL Life Technologies, Inc.) and size-fractionated by sucrose gradient centrifugation as described by Sambrook and colleagues (1989). DNA ranging from 16 to $30 \mathrm{~kb}$ were ligated into cosmid vector pLAFR3 after BamHI digestion and alkaline phosphatase (Boehringer Mannheim, Indianapolis, IN, U.S.A.) treatment. Recombinant cosmids were packaged using Gigapack II packing extracts (Stratagene) and then used to infect $E$. coli strain XL1-Blue MR according to the manufacturer's instructions; $\alpha$-complementation was used to select colonies harboring an insert. The library was amplified using standard procedures (Sambrook et al. 1989). Approximately 1,000 colonies were selected from the primary library and 3,000 colonies were selected from the amplified library representing approximately 10 genome equivalents. All colonies were individually picked into separate microtiter wells containing $100 \mu \mathrm{l}$ of LB broth plus tetracycline. The microtiter plates were incubated overnight at $37^{\circ} \mathrm{C}$ as still cultures. The next day, $10-\mu \mathrm{l}$ aliquots were used to reinoculate a microtiter plate containing $100 \mu \mathrm{l}$ of fresh LB plus tetracycline and incubated overnight at $37^{\circ} \mathrm{C}$ to ensure uniform growth. A $10-\mu \mathrm{l}$ aliquot of each well was spotted in duplicate onto GeneScreen membrane filters (NEN Life Science Products, Boston, MA, U.S.A.), placed on LB agar plus tetracycline, and incubated overnight at $37^{\circ} \mathrm{C}$. The resultant colonies were lysed with denaturing solution $(0.5 \mathrm{M} \mathrm{NaOH}, 1.5 \mathrm{M}$ $\mathrm{NaCl})$ and neutralized (0.5 M Tris- $\mathrm{HCl}, \mathrm{pH} 7.2 ; 1.5 \mathrm{M} \mathrm{NaCl}$; $100 \mathrm{mM}$ EDTA). The DNA were fixed to the membrane by baking at $80^{\circ} \mathrm{C}$ for $2 \mathrm{~h}$ under a vacuum. Glycerol $(50 \mu \mathrm{l}$ of sterile $80 \%$ stock) was added to the remaining $130 \mu \mathrm{l}$ of culture in each well of the microtiter plates, mixed, and stored at $-80^{\circ} \mathrm{C}$.

\section{CHEF-PFGE.}

The procedures used for isolation, digestion, and electrophoresis of $P$. syringae pv. syringae genomic DNA were modified from work by Rainey and colleagues (1993). P. syringae pv. syringae strains were grown overnight in $5 \mathrm{ml}$ of NBY liquid medium. Cells were harvested by centrifugation and washed twice in sodium chloride-ethyenedinitrilo tetraacetic acid-Tris buffer (NET 100) buffer (100 mM NaCl; $100 \mathrm{mM}$ EDTA; $10 \mathrm{mM}$ Tris-HCl, $\mathrm{pH}$ 8.0). To form agarose plugs, the washed cells were resuspended in $1 \mathrm{ml}$ of NET 100, mixed with an equal volume of $2 \%$ (wt/vol) chromosomal grade agarose, prepared in NET 100, and aliquoted into well molds. The $P$. syringae pv. syringae cells suspended in agarose were then placed in a lysis solution $(6 \mathrm{mM}$ Tris- $\mathrm{HCl}, \mathrm{pH} 7.6 ; 1 \mathrm{M} \mathrm{NaCl}$; $100 \mathrm{mM}$ EDTA, pH 8.0; $0.5 \%$ sarkosyl; $1 \mathrm{mg}$ of lysozyme per $\mathrm{ml})$ at $37^{\circ} \mathrm{C}$ for $24 \mathrm{~h}$, followed by a second lysis solution $(0.5 \mathrm{M}$ EDTA, pH 9.0; $1 \%$ sarkosyl; $1.5 \mathrm{mg}$ of proteinase $\mathrm{K}$ per $\mathrm{ml}$ ) incubated at $50^{\circ} \mathrm{C}$ for $48 \mathrm{~h}$. The agarose blocks were finally treated with $50 \mathrm{mM}$ phenylmethylsulfonyl fluoride for $2 \mathrm{~h}$ to inhibit proteinase $\mathrm{K}$ activity and stored in $0.5 \mathrm{M}$ EDTA at $4^{\circ} \mathrm{C}$. DNA plugs were placed in $1 \times$ Tris-EDTA (TE) $(\mathrm{pH} 7.6)$ for $12 \mathrm{~h}$ (overnight) at $4^{\circ} \mathrm{C}$, transferred to fresh $1 \times \mathrm{TE}(\mathrm{pH}$ 7.6), and incubated for $1 \mathrm{~h}$ at room temperature. DNA plugs were then equilibrated twice with $1 \times$ restriction buffer at room temperature for $1 \mathrm{~h}$. The $1 \times$ restriction buffer was replaced with $1 \mathrm{ml}$ of fresh $1 \times$ restriction buffer and the DNA, suspended in agarose plugs, were digested $\left(37^{\circ} \mathrm{C}\right.$ for $\left.24 \mathrm{~h}\right)$ using $20 \mathrm{U}$ of $\mathrm{DraI}$ restriction endonuclease (Gibco-BRL Life Technologies, Inc.).
Agarose blocks containing digested $P$. syringae pv. syringae DNA were loaded onto a $1.0 \%$ agarose, $0.5 \times$ Tris-borateEDTA (TBE)-buffered gel and run on a CHEF DRII pulsedfield electrophoresis system (Bio-Rad Laboratories, Inc., Hercules, CA, U.S.A.) containing $0.5 \times \mathrm{TBE}$ buffer cooled to $5^{\circ} \mathrm{C}$. A ramped pulse time of 5 to $10 \mathrm{~s}$ over $20 \mathrm{~h}$ at $175 \mathrm{~V}$ was used to resolve the DNA fragments. Gels were stained in ethidium bromide $(10 \mu \mathrm{g} / \mathrm{ml})$ for $30 \mathrm{~min}$ at room temperature and destained in SDW for $1 \mathrm{~h}$ before visualization. Sizes were estimated by comparison with comigrating fragments of lambdaladder PFG and low-range PFG marker (New England Biolabs, Beverly, MA, U.S.A.). The resultant gel was transferred to a Hybond membrane (Amersham Pharmacia Biotech, Inc., Piscataway, NJ, U.S.A.) for Southern analysis using standard procedures (Sambrook et al. 1989).

\section{Identification and characterization of cosmids that hybridize to the approximately $145-\mathrm{kb}$ DraI fragment.}

The B301D genomic library was screened using the approximately 145-kb DraI fragment excised from a CHEFPFGE gel as a hybridization probe. Cosmids identified and confirmed to hybridize with the approximately $145-\mathrm{kb}$ DraI fragment were chosen for further characterization (Table 1). Restriction maps were generated for each cosmid, and small fragments from either end of the cosmids were gel-purified using the Qiaex II gel extraction kit (Qiagen, Inc., Valencia, CA, U.S.A.). Overlapping cosmids were identified using these fragments as hybridization probes. In addition, the small fragments were used as hybridization probes against the library in order to identify more cosmids that hybridized with the approximately 145-kb DraI fragment.

Cosmids hybridizing to the approximately 145-kb DraI fragment of $P$. syringae pv. syringae strain B301D were not all contiguous, and cosmid walking did not identify new cosmids from the library. DNA fragments from the ends of noncontiguous cosmids were used as hybridization probes against B301D genomic DNA digested with various restriction endonucleases to identify large DNA fragments that span the genomic gap. Large DNA fragments were isolated by gel purification and ligated into pBluescript II SK in order to construct a subgenomic library. This subgenomic library was screened using the DNA fragments from the gap region as a hybridization probe. Positive clones were chosen for further characterization as described above.

\section{Construction of mini-Tn5 disruptions and introduction of these disruptions into the genome}

of $P$. syringae pv. syringae strain BR334 by marker exchange.

Using the restriction map constructed from the overlapping cosmids, fragments chosen for subcloning were located approximately 15 to $20 \mathrm{~kb}$ apart along the approximately 145-kb DraI fragment. Fragments were isolated by gel purification from selected cosmids and subcloned into pBluescript II SK. Each of the new subclones was mapped using restriction endonucleases, and unique restriction sites were identified within each subclone. The subclones carried in pBluescript II SK were then digested using the unique restriction endonuclease and polished using T4 DNA polymerase (Gibco-BRL Life Technologies, Inc.) to create blunt ends. The mini-Tn5 cassette (de Lorenzo and Timmis 1994) was digested with SmaI, gel-purified, and bluntend-ligated into the respective subclones to construct a disrup- 
tion in the DNA sequence. The DNA flanking the mini-Tn5 cassette were sequenced using primers constructed to prime forward and reverse directions on the mini- $\mathrm{Tn} 5$ cassette (forward: 5' GGCTTCGAAATCGTTTTC 3'; reverse: 5' GCTCACAGCCAAACTATC $3^{\prime}$ ). The inserts from each subclone carrying the mini-Tn5 cassette were then gel-purified and ligated into pBR325. These constructs were introduced by electroporation into competent cells of DH10B for maintenance of the plasmid and into competent $P$. syringae pv. syringae cells of strains B301D and BR334 for marker exchange mutagenesis as described by Scholz-Schroeder (2001). Resultant $\mathrm{Km}^{\mathrm{r}}$ colonies were screened for loss of the vector and presence of the mini-Tn5 cassette by Southern hybridization (Table 1). Recombinant $P$. syringae pv. syringae strains were screened for syringopeptin and syringomycin production using the bioassays described above. Complementation in trans for each insertion was performed by introduction of the parental cosmid by electroporation into the mutant strain as described by Scholz-Schroeder (2001).

\section{Construction of the insertional mutagenesis map of the approximately 145-kb DraI fragment.}

DNA from recombinant $P$. syringae pv. syringae strains carrying the mini- $\operatorname{Tn} 5$ cassette were analyzed by CHEF-PFGE as described above. The DNA were then transferred to Hybond membrane (Amersham Pharmacia Biotech, Inc.) for Southern analysis. In addition, all $P$. syringae pv. syringae mutant strains were analyzed by traditional gel electrophoresis and Southern hybridization for confirmation of the low-molecularweight fragments. The probe for Southern analysis consisted of a pool of DNA from all the cosmids that hybridized to the approximately 145-kb DraI fragment and lambda DNA for hybridization to the molecular weight markers. The size of the Tn3HoHo1 $(14.25 \mathrm{~kb})$ is quite large and it was taken into account when constructing the restriction map. We identified one DraI site near the end of the Tn3HoHol insertion, most likely within the tnpA gene. This added approximately $11 \mathrm{~kb}$ to the large arm of the DraI fragment. It is important to note that the size estimates for the large and the small arms of the DraI fragment were made not only with the CHEF-PFGE restriction mapping, but also with the restriction mapping of the cosmids. Using the information together, the size estimates and location of the various insertions were completed.

\section{ACKNOWLEDGMENTS}

Special thanks to M. L. Hutchison for construction of the Pseudomonas syringae pv. syringae strain B301D genomic library. This work was supported by grant 2001-35319-10400 from the National Research Initiative Competitive Grants Program of the U.S. Department of Agriculture, Science and Education Administration to D. Gross. This work was also supported, in part, by grants of the "Istituto Pasteur-Fondazione Cenci Bolognetti," Universita di Roma "La Sapienza," the Italian Ministry of University and Technological Research (MURST), and the Italian National Research Council (CNR)-Target Project on Biotechnology to I. Grgurina. PPNS No. 0321, Department of Plant Pathology, College of Agriculture and Home Economics Research Center, Washington State University, Pullman 99164-6430 U.S.A. This paper is dedicated to Antonio Graniti on the occasion of his 75 th birthday.

\section{LITERATURE CITED}

Alfano, J. R., Charkowski, A. O., Deng, W. L., Badel, J. L., PetnickiOcwieja, T., van Dijk, K., and Collmer, A. 2000. The Pseudomonas syringae Hrp pathogenicity island has a tripartite mosaic structure composed of a cluster of type III secretion genes bounded by exchangeable effector and conserved effector loci that contribute to parasitic fitness and pathogenicity in plants. Proc. Natl. Acad. Sci. U.S.A. 97:4856-4861.

Altschul, S. F., Gish, W., Miller, W., Myers, E. W., and Lipman, D. J. 1990. Basic local alignment search tool. J. Mol. Biol. 215:403-410.

Ausubel, F. M., Brent R., Kingston, R. E., Moore, D. D., Seidman, J. G., Smith, J. A., and Struhl, K. 1990. Current protocols in molecular biology. Green Publishing Associates and Wiley Interscience, New York.

Ballio, A., Bossa, F., DiGiorgio, D., DiNola, A., Manetti, C., Paci, M., Scaloni, A., and Segre, A. L. 1995. Solution conformation of the Pseudomonas syringae pv. syringae phytotoxic lipodepsipeptide syringopeptin 25-A. Two-dimensional NMR, distance geometry and molecular dynamics. Eur. J. Biochem. 234:747-758.

Bender, C. L., Alarcón-Chaidez, F., and Gross, D. C. 1999. Pseudomonas syringae phytotoxins: Mode of action, regulation, and biosynthesis by peptide and polyketide synthetases. Microbiol. Mol. Biol. Rev. 63:266-292.

Blattner, F. R., Plunkett, G., III, Bloch, C. A., Perna, N. T., Burland, V., Riley, M., Collado-Vides, J., Glasner, J. D., Rode, C. K., Mayhew, G. F., Gregor, J., Davis, N. W., Kirkpatrick, H. A., Goeden, M. A., Rose, D. J., Mau, B., and Shao, Y. 1997. The complete genome sequence of Escherichia coli K-12. Science 277:1453-1474.

Bradbury, J. F. 1986. Pseudomonas. Pages 175-177 in: Guide to Plant Pathogenic Bacteria. CAB Int. Mycol. Inst., Kew, Surrey, England.

Bultreys, A., and Gheysen, I. 1999. Biological and molecular detection of toxic lipodepsipeptide-producing Pseudomonas syringae strains and PCR identification in plants. Appl. Environ. Microbiol. 65:19041909.

Caponero, A., Hutchison, M. L., Iacobellis, N. S., and Gross, D. C. 1997. Isolation and characterization of mutants of Pseudomonas syringae pv. syringae defective in production of syringopeptins. Pages 202-207 in: Pseudomonas syringae Pathovars and Related Pathogens. K. Rudolph, T. J. Burr, J. W. Mansfield, D. Stead, A. Vivian, and J. von Kietzell, eds. Kluwer Academic Publishers, Dordrecht, The Netherlands.

Cody, Y. S., Gross, D. C., Proebsting, E. L., Jr., and Spotts, R. A. 1987. Suppression of ice nucleation-active Pseudomonas syringae by antagonistic bacteria in fruit tree orchards and evaluations of frost control. Phytopathology 77:1036-1044.

de Lorenzo, V., and Timmis, K. N. 1994. Analysis and construction of stable phenotypes in gram-negative bacteria with Tn5- and Tn10derived minitransposons. Methods Enzymol. 235:386-405.

Del Sal, G., Manfioletti, G., and Schneider, C. 1989. The CTAB-DNA precipitation method: A common mini-scale preparation of template DNA from phagmids, phages or plasmids suitable for sequencing. Biotechniques 7:514-520.

Devereux, J., Haeberli, P., and Smithies, O. 1984. A comprehensive set of sequence analysis programs for the VAX. Nucleic Acids Res. 12:387-395.

Fonstein, M., and Haselkorn, R. 1995. Physical mapping of bacterial genomes. J. Bacteriol. 177:3361-3369.

Fukuchi, N., Isogai, A., Nakayama, J., Takayama, S., Yamashita, S., Suyama, K., Takemoto, J. Y., and Suzuki, A. 1992. Structure and stereochemistry of three phytotoxins, syringomycin, syringotoxin and syringostatin, produced by Pseudomonas syringae pv. syringae. J. Chem. Soc. Perkin Trans. I 9:1149-1157.

Grgurina, I., and Benincasa, M. 1994. Evidence of the nonribosomal biosynthetic mechanism in the formation of syringomycin and syringopeptin, bioactive lipodepsipeptides of the phytopathogenic bacterium Pseudomonas syringae pv. syringae. Ital. Biochem. Soc. Trans. 5:143.

Grgurina, I., Gross, D. C., Iacobellis, N. S., Lavermicocca, P., Takemoto, J. Y., and Benincasa, M. 1996. Phytotoxin production by Pseudomonas syringae pv. syringae: Syringopeptin production by syr mutants defective in biosynthesis or secretion of syringomycin. FEMS (Fed. Eur. Microbiol. Soc.) Microbiol. Lett. 138:35-39.

Gross, D. C. 1991. Molecular and genetic analysis of toxin production by pathovars of Pseudomonas syringae. Annu. Rev. Phytopathol. 29: 247-278.

Gross, D. C., and DeVay, J. E. 1977. Population dynamics and pathogenesis of Pseudomonas syringae in maize and cowpea in relation to the in vitro production of syringomycin. Phytopathology 67:475-483.

Guenzi, E., Galli, G., Grgurina, I., Gross, D. C., and Grandi, G. 1998. Characterization of the syringomycin synthetase gene cluster-A link 
between prokaryotic and eukaryotic peptide synthetases. J. Biol. Chem. 273:32857-32863

Hacker, J., and Kaper, J. B. 2000. Pathogenicity islands and the evolution of microbes. Annu. Rev. Microbiol. 54:641-679.

Hanahan, D. 1985. Techniques for transformation of E. coli. Pages 109135 in: DNA Cloning : A Practical Approach, Vol. I. D. M. Glover, ed. IRL Press, Washington, D.C., U.S.A.

Herrero, M., DeLorenzo, V., and Timmis, K. N. 1990. Transposon vectors containing non-antibiotic resistance selection markers for cloning and stable chromosomal insertion of foreign genes in Gram-negative bacteria. J. Bacteriol. 172:6557-6567.

Hutchison, M. L., and Gross, D. C. 1997. Lipopeptide phytotoxins produced by Pseudomonas syringae pv. syringae: Comparison of the biosurfactant and ion channel-forming activities of syringopeptin and syringomycin. Mol. Plant-Microbe Interact. 10:347-354.

Iacobellis, N. S., Lavermicocca, P., Grgurina, I., Simmaco, M., and Ballio, A. 1992. Phytotoxic properties of Pseudomonas syringae pv. syringae toxins. Physiol. Mol. Plant Pathol. 40:107-116.

Kitten, T., Kinscherf, T. G., McEvoy, J. L., and Willis, D. K. 1998. A newly identified regulator is required for virulence and toxin production in Pseudomonas syringae. Mol. Microbiol. 28:917-929.

Lavermicocca, P., Iacobellis, N. S., Simmaco, M., and Graniti, A. 1997. Biological properties and spectrum of activity of Pseudomonas syringae pv. syringae toxins. Physiol. Mol. Plant Pathol. 50:129-140.

Lawrence, J. G., and Roth, J. R. 1996. Selfish operons: Horizontal transfer may drive the evolution of gene clusters. Genetics 143:1843-1860.

Lehoux, D. E., Sanschagrin, F., and Levesque, R. C. 2000. Genomics of the $35-\mathrm{kb} p v d$ locus and analysis of novel $p v d I J K$ genes implicated in pyoverdine biosynthesis in Pseudomonas aeruginosa. FEMS (Fed. Eur. Microbiol. Soc.) Microbiol. Lett. 190:141-146.

Marahiel, M. A., Stachelhaus, T., and Mootz, H. D. 1997. Modular peptide synthetases involved in nonribosomal peptide synthesis. Chem. Rev. 97:2651-2673.

Mo, Y.-Y., and Gross, D. C. 1991. Expression in vitro and during plant pathogenesis of the $s y r B$ gene required for syringomycin production by Pseudomonas syringae pv. syringae. Mol. Plant-Microbe Interact. 4:28-36.

Moffitt, M. C., and Neilan, B. A. 2000. The expansion of mechanistic and organismic diversity associated with non-ribosomal peptides. FEMS (Fed. Eur. Microbiol. Soc.) Microbiol. Lett. 191:159-167.

Prentki, P., Karch, F., Iida, S., and Meyer, J. 1981. The plasmid cloning vector pBR325 contains a 482 base-pair-long inverted duplication. Gene 14:289-299.

Quigley, N. B., and Gross, D. C. 1994. Syringomycin production among strains of Pseudomonas syringae pv. syringae: Conservation of the $s y r B$ and $s y r D$ genes and activation of phytotoxin production by plant signal molecules. Mol. Plant-Microbe Interact. 7:78-90.

Quigley, N. B., Mo, Y.-Y., and Gross, D. C. 1993. SyrD is required for syringomycin production by Pseudomonas syringae pathovar syringae and is related to a family of ATP-binding secretion proteins. Mol. Microbiol. 9:787-801.

Rainey, P. B., Brodey, C. L., and Johnstone, K. 1993. Identification of a gene cluster encoding three high-molecular-weight proteins, which is required for synthesis of tolaasin by the mushroom pathogen Pseudomonas tolaasii. Mol. Microbiol. 8:643-652.

Ratnaningsih, E., Dharmsthiti, S., Krishnapillai, V., Morgan, A., Sinclair, M., and Holloway, B. W. 1990. A combined physical and genetic map of Pseudomonas aeruginosa PAO. J. Gen. Microbiol. 136:2351-2357.

Rich, J. J., and Willis, D. K. 1997. Multiple loci of Pseudomonas syringae pv. syringae are involved in pathogenicity on bean: Restoration of one lesion-deficient mutant requires two tRNA genes. J. Bacteriol. 179:2247-2258.

Römling, U., Grothues, D., Bautsch, W., and Tummler, B. 1989. A physical genome map of Pseudomonas aeruginosa PAO. EMBO (Eur. Mol. Biol. Organ.) J. 8:4081-4089.

Sambrook J., Frisch, E. F., and Maniatis, T. 1989. Molecular Cloning: A
Laboratory Manual. Cold Spring Harbor Laboratory Press, Cold Spring Harbor, NY, U.S.A.

Scholz, B. K., and Gross, D. C. 1996. Genetic characterization of a synthetase of Pseudomonas syringae pv. syringae involved in syringomycin synthesis. Phytopathology (Abstr.) 86:S76.

Scholz-Schroeder, B. K. 2001. Electroporation and marker exchange mutagenesis of Pseudomonas syringae pv. syringae. The Plant Health Instructor DOI: 10.1094/PHI-I-2001-0424-01.

Scholz-Schroeder, B. K., Hutchison, M. L, Grgurina, I., and Gross, D. C. 2001. The contribution of syringopeptin and syringomycin to virulence of Pseudomonas syringae pv. syringae strain B301D on the basis of sypA and syrB1 biosynthesis mutant analysis. Mol. PlantMicrobe Interact. 14:336-348.

Segre, A., Bachmann, R. C., Ballio, A., Bossa, F., Grgurina, I., Iacobellis, N. S., Marino, G., Pucci, P., Simmaco, M., and Takemoto, J. Y. 1989. The structure of syringomycins $A_{1}$, E and G. FEBS (Fed. Eur. Biochem. Soc.) Lett. 255:27-31.

Shortridge, V. D., Pato, M. L., Vasil, A. I., and Vasil, M. L. 1991. Physical mapping of virulence-associated genes in Pseudomonas aeruginosa by transverse alternating-field electrophoresis. Infect. Immun. 59:3596-3603.

Spiers, A. J., Buckling, A., and Rainey, P. B. 2000. The causes of Pseudomonas diversity. Microbiology 146:2345-2350.

Staskawicz, B., Dahlbeck, D., Keen, N., and Napoli, C. 1987. Molecular characterization of cloned avirulence genes from race 0 and race 1 of Pseudomonas syringae pv. glycinea. J. Bacteriol. 169:5789-5794.

Stein, T., and Vater, J. 1996. Amino acid activation and polymerization at modular multienzymes in nonribosomal peptide biosynthesis. Amino Acids 10:201-227.

Stover, C. K., Pham, X. Q., Erwin, A. L., Mizoguchi, S. D., Warrener, P., Hickey, M. J., Brinkman, F. S. L., Hufnagle, W. O., Kowalik, D. J., Lagrou, M., Garber, R. L., Goltry, L., Tolentino, E., WestbrockWadman, S., Yuan, Y., Brody, L. L., Coulter, S. N., Folger, K. R., Kas, A., Larbig, K., Lim, R., Smith, K., Spencer, D., Wong, G. K. S., Wu, Z., Paulsen, I. T., Reizer, J., Saier, M. H., Hancock, R. E. W., Lory, S., and Olson, M. V. 2000. Complete genome sequence of Pseudomonas aeruginosa PAO1, an opportunistic pathogen. Nature 406:959-964.

Vaillo, E., Ballio, A., Luisi, P. L., and Thomas, R. M. 1992. The spectroscopic properties of the lipodepsipeptide, syringomycin-E. Biopolymers 32:1317-1326.

Van Bambeke, F., Balzi, E., and Tulkens, P. M. 2000. Antibiotic efflux pumps. Biochem. Pharmacol. 60:457-470.

Vidaver, A. K. 1967. Synthetic and complex media for the rapid detection of fluorescence of phytopathogenic pseudomonads: Effect of the carbon source. Appl. Microbiol. 15:1523-1524.

Weber, G., Schörgendorfer, K., Schneider-Scherzer, E., and Leitner, E. 1994. The peptide synthetase catalyzing cyclosporine production in Tolypocladium niveum is encoded by a giant 45.8-kilobase open reading frame. Curr. Genet. 26:120-125.

Xu, G.-W., and Gross, D. C. 1988a. Evaluation of the role of syringomycin in plant pathogenesis by using Tn5 mutants of Pseudomonas syringae pv. syringae defective in syringomycin production. Appl. Environ. Microbiol. 54:1345-1353.

Xu, G.-W., and Gross, D. C. 1988b. Physical and functional analyses of the $s y r A$ and $s y r B$ genes involved in syringomycin production by Pseudomonas syringae pv. syringae. J. Bacteriol. 170:5680-5688.

Yanisch-Perron, C., Vieira, J., and Messing, J. 1985. Improved M13 phage cloning vectors and host strains: Nucleotide sequences of the M13mp18 and pUC19 vectors. Gene 33:103-119.

Zhang, J.-H., Quigley, N. B., and Gross, D. C. 1995. Analysis of the syrB and $\operatorname{syr} C$ genes of Pseudomonas syringae pv. syringae indicates that syringomycin is synthesized by a thiotemplate mechanism. J. Bacteriol. 177:4009-4020.

Zhang, J.-H., Quigley, N. B., and Gross, D. C. 1997. Analysis of the syrP gene, which regulates syringomycin synthesis by Pseudomonas syringae pv. syringae. Appl. Environ. Microbiol. 63:2771-2778. 